\title{
Effects of Electron Beam Irradiation on Pathogen Inactivation, Quality, and Functional Properties of Shell Egg during Ambient Storage
}

\author{
Hyun Joo Kim, Hyejeong Yun', Samooel Jung ${ }^{1}$, Yeonkuk Jung ${ }^{1}$, Keehyuk Kim², \\ Ju Woon $\mathrm{Lee}^{3}$, and Cheorun $\mathrm{Jo}^{1 *}$ \\ Department of Food Science and Technology, Chung-Ang University, Anseong 456-756, Korea \\ ${ }^{I}$ Department of Animal Science and Biotechnology, Chungnam National University, Daejeon 305-764, Korea \\ ${ }^{2}$ Department of Culinary Nutrition, Woosong University, Daejeon 300-718, Korea \\ ${ }^{3}$ Radiation Food Science and Biotechnology, Advanced Radiation Research Institute, Jeongeup 580-185, Korea
}

\begin{abstract}
This study investigated the effects of electron beam irradiation on pathogens, quality, and functional properties of shell eggs during storage. A 1st grade 1-d-old egg was subjected to electron beam irradiation at $0,1,2$, and $3 \mathrm{kGy}$, after which the number of total aerobic bacteria, reduction of inoculated Escherichia coli and Salmonella Typhimurium, egg quality, and functional properties were measured. Electron beam irradiation at $2 \mathrm{kGy}$ reduced the number of $E$. coli and $S$. Typhimurium cells to a level below the detection limit $\left(<10^{2} \mathrm{CFU} / \mathrm{g}\right)$ after 7 and $14 \mathrm{~d}$ of storage. Egg freshness as measured by albumen height and the number of Haugh units was significantly reduced by 1-kGy irradiation. The viscosity of irradiated egg white was also significantly decreased by increased irradiation, whereas its foaming ability was increased. Electron beam irradiation also increased lipid oxidation in egg yolks. These results suggest that electron beam irradiation reduces the freshness of shell eggs while increasing the oxidation of egg yolk and improving important functional properties such as foaming capacity. Electron beam irradiation can also be applied to the egg breaking process since the irradiation reduces the viscosity of egg white, which can allow egg whites and yolks to be separated with greater efficiency.
\end{abstract}

Key words: egg, electron beam, pathogen, quality, functional property

\section{Introduction}

Eggs are consumed on a daily basis throughout the world (Cook and Briggs, 1986) and are a highly nutritious as well as low-cost source of protein (Theron et al., 2003). However, eggs are highly perishable, undergoing rapid degradation during the time period from collection to consumption. Bacterial contamination of egg has been shown to be mainly environmental, as aerosolized fecal particles can settle on eggs along with associated microorganisms (Theron et al., 2003). More importantly, bacteria on the surface of the egg can pass through pores in the shell and contaminate the interior, despite physical barriers that prevent microbial growth such as albumen in the egg white (Frazier and Westhoff, 1988).

Reports have found that undercooked and raw shell

\footnotetext{
*Corresponding author: Cheorun Jo, Department of Animal Science and Biotechnology, Chungnam National University, Daejeon 305-764, Korea. Tel: 82-42-821-5774, Fax: 82-42825-9754, E-mail: cheorun@cnu.ac.kr
}

eggs are the major cause of Salmonella Enteritidis (SE) infection in humans (CDC, 2003). In addition, the frequency of salmonellosis caused by SE has steadily increased over in the United States from 1985 to 1999, with $80 \%$ of all cases associated with eggs or egg-containing products (Patrick et al., 2004). To destroy bacteria on the egg surface at food processing level, many methods such as washing with antimicrobial solutions, heat, and UV irradiation have been applied. However, none of these techniques are effective against internal Salmonella contamination since the bacteria are sheltered from by the egg shell (Sommers and Fan, 2006).

Irradiation is a nonthermal method that can eliminate food-borne pathogens such as Salmonella, Escherichia coli, and Listeria from inside shell eggs. As a cold pasteurization technique, electron beam irradiation is more attractive for the elimination of pathogens in heat-sensitive products like fresh shell eggs (Tellez et al., 1995). Narvaiz et al. (1992) reported that irradiation above 2 kGy controls Salmonella and other pathogens in egg yolk, whereas Serrano et al. (1997) suggested that SE in 
shell eggs and liquid whole eggs could be effectively reduced (approximately 4 logs) by $1.5 \mathrm{kGy}$ of irradiation. The US Food and Drug Administration approved the irradiation of shell egg at doses up to $3 \mathrm{kGy}$ (USDA FSIS, 2000).

Among the sources of radiation used on food, the major limitation of electron beam irradiation is its limited penetration up to a maximum of about $8 \mathrm{~cm}$ at $10 \mathrm{MeV}$ (Miller, 2005). Despite this, electron beam irradiation can be used on products such as grain or low-density foods such as ground spices, as well as for the removal of surface contamination on prepared meals. One consequence of the so-called "switch-off capability" of electron beam irradiation is that the technology can be integrated with food processing operations. Mitchell (1994) stated that although both radioisotopic (gamma ray) and machine sources (electron beam and X-ray) have the same level of impact on food, consumers would react more favorably to machine sources due to the association of isotopes with the nuclear industry. However, there is limited information available on the effect electron beam irradiation has on the safety, quality, and functional properties of shell egg.

Therefore, the objective of this study was to determine the safety level, quality, and functional properties of shell egg after electron beam irradiation and subsequent storage at ambient temperature.

\section{Materials and Methods}

\section{Sample preparation and electron beam irradiation}

Clean, medium-sized ( $65 \pm 2 \mathrm{~g}$ ) 1-day-old eggs (the $1^{\text {st }}$ grade) were purchased from Namsan poultry farm (Gongju, Korea). The eggs were irradiated in a paper box using a linear electron beam RF accelerator (Energy $2.5 \mathrm{MeV}$, beam power $40 \mathrm{~kW}$, EB Tech, Daejeon, Korea) at $10 \pm$ $0.5^{\circ} \mathrm{C}$. Irradiation was performed in the presence of air and at a conveyor velocity of $10 \mathrm{~m} / \mathrm{min}$. To confirm the target dose, alanine dosimeters attached to the top and bottom surfaces of the sample pack were read using a 104 Electron Paramagnetic Resonance unit (EMS-104, Bruker Instruments Inc., Bullerica, MA) after treatment.

\section{Microbial analysis}

The prepared sample (10 g) was homogenized using a stomacher (bag mixer ${ }^{\circledR} 400$, Interscience Co, France) for $2 \mathrm{~min}$ in a sterile stomacher bag containing $90 \mathrm{~mL}$ of sterile saline solution. Media for the enumeration of total aerobic bacteria, yeast and mold were performed on total plate count agar (Difco Laboratories, Detroit, MI, USA), after which the plates were incubated at $37^{\circ} \mathrm{C}$ for $48 \mathrm{~h}$. The colony forming units (CFU) per gram were counted at a dilution of 30 to $300 \mathrm{CFU}$ per plate.

Escherichia coli (KCTC 1682) and Salmonella Typhimurium (KCTC 1925) were seeded in $100 \mathrm{~mL}$ of tryptic soy broth medium and incubated at $37^{\circ} \mathrm{C}$ for $20 \mathrm{~h}$ with constant shaking at $190 \mathrm{rpm}$. Bacteria were then transferred to a sterile rack for air-drying at room temperature, followed by electron beam irradiation for 1, 2, and $3 \mathrm{kGy}$ under the same conditions explained in Section 2.1. The inoculated eggs were kept at room temperature, and the total plate count was measured at days 0,3 , and 7 following serial dilution and incubation at $37^{\circ} \mathrm{C}$ for $48 \mathrm{~h}$ on tryptic soy agar.

\section{Egg quality and functional property}

Yolk color, albumen height $(\mathrm{mm})$, and Haugh units were measured using the QCM+ System (Technical Services and Supplies, York, England). Emulsion capacity of egg yolk was determined according to Cho et al. (1999).

The foaming capacity and foaming stability of egg white were measured using the modified method of Phillips et al. (1990). Egg white $(25 \mathrm{~mL})$ was mixed with $25 \mathrm{~mL}$ of deionized distilled water in a $100 \mathrm{~mL}$ graduated cylinder, followed by homogenization at $24,200 \mathrm{~g}$ for $30 \mathrm{~s}$ using a homogenizer (T25B, IKA, Staufen, Germany). The foam height was measured as foaming capacity. Foam stability was determined by measuring the water content in the graduated cylinder after 30 min of foaming at room temperature. A higher value represents lower foam stability.

The $\mathrm{pH}$ values of egg white and yolk were determined using a $\mathrm{pH}$ meter (Model $750 \mathrm{P}$, iSTEC, Seoul, KOREA) after diluting the samples with 9 volumes of DDW. Viscosity was measured using a viscometer (Model VT-03F, Rion, Tokyo, Japan).

\section{Lipid oxidation of egg yolk}

Egg yolk samples were mixed by hand for $30 \mathrm{~s}$, and the 2-thiobarbituric acid reactive substance (TBARS) method was used to measure lipid oxidation (Jo et al., 2002). Samples $(5 \mathrm{~g})$ in $15 \mathrm{~mL}$ of deionized distilled water (DDW) were homogenized using $50 \mu \mathrm{L}$ of BHA (7.2\%) for $15 \mathrm{~s}$. Two milliliters of the homogenate was then transferred to a disposable test tube, after which $4 \mathrm{~mL}$ of 2-thiobarbituric acid (TBA)/trichloroacetic acid (TCA) (20 mM TBA in 15\% TCA) solution was added. The mixture was blended and incubated in a boiling water bath for $15 \mathrm{~min}$. The sample was then cooled in cold water for 10 
min and then centrifuged for $15 \mathrm{~min}$ at $2,500 \mathrm{~g}$ and $4^{\circ} \mathrm{C}$. Absorbance was measured at $532 \mathrm{~nm}$, and lipid oxidation was reported as mg malondialdehyde/kg sample.

\section{Statistical analysis}

Statistical analysis was performed by one-way analysis of variance (ANOVA). Significant differences among mean values were identified by Duncan's multiple range test using SAS software with a confidence level of $p \leq 0.05$. Mean values and standard errors of the mean are reported.

\section{Results and Discussion}

\section{Microbial analysis}

The total aerobic bacterial population of shell egg was 2.24 Log CFU/g (data not shown). No viable cells were observed immediately following electron beam irradiation or during storage. Kim et al. (2008) also reported that $S$. Typhimurium was eliminated from shell egg by gamma irradiation at $3 \mathrm{kGy}$, whereas $E$. coli and $S$. sciuri were eliminated by gamma irradiation at $5 \mathrm{kGy}$.

The original number of $E$. coli and $S$. Typhimurium cells inoculated on shell egg was $4.74 \mathrm{Log} \mathrm{CFU} / \mathrm{g}$, and irradiation at $3 \mathrm{kGy}$ reduced this value by about $3 \mathrm{log}$ cycles at day 0 (Table 1). Viable cell counts in egg at day 0 were lower compared to days 3 and 7 . Shell egg acts as the first barrier against microbial attack due to its harsh conditions such as limited water and nutrient content (Liu et al., 2009). A previous study indicated that inoculated pathogens such as $S$. Typhimurium are eliminated by 2

Table 1. Effect of electron beam irradiation on survival of Escherichia coli and Salmonella Typhimurium inoculated on shell egg during ambient storage

\begin{tabular}{ccccl}
\hline \hline \multirow{2}{*}{ Pathogens } & Irradiation & \multicolumn{3}{c}{ Storage period (d) } \\
\cline { 3 - 5 } & dose (kGy) & 0 & 7 & 14 \\
\hline \multirow{3}{*}{$\begin{array}{c}\text { Escherichia } \\
\text { coli }\end{array}$} & 0 & $4.74^{\mathrm{a}}$ & $4.39^{\mathrm{a}}$ & $3.65^{\mathrm{a}}$ \\
& 2 & $3.98^{\mathrm{b}}$ & $4.05^{\mathrm{b}}$ & $3.46^{\mathrm{a}}$ \\
& 3 & $2.28^{\mathrm{c}}$ & $\mathrm{nd}^{\mathrm{c}, 1)}$ & $\mathrm{nd}^{\mathrm{b}}$ \\
& $\mathrm{SEM}^{2)}$ & 0.18 & 0.06 & 0.05 \\
\hline Salmonella & 0 & $4.78^{\mathrm{c}}$ & $4.33^{\mathrm{a}}$ & $3.87^{\mathrm{a}}$ \\
Typhimurium & 1 & $3.94^{\mathrm{b}}$ & $4.12^{\mathrm{a}}$ & $3.63^{\mathrm{b}}$ \\
& 2 & $2.37^{\mathrm{c}}$ & $2.15^{\mathrm{b}}$ & $\mathrm{nd}^{\mathrm{c}}$ \\
& 3 & $1.43^{\mathrm{d}}$ & $\mathrm{nd}^{\mathrm{c}}$ & $\mathrm{nd}^{\mathrm{c}}$ \\
& $\mathrm{SEM}^{2)}$ & 0.13 & 0.28 & 0.03
\end{tabular}

${ }^{\mathrm{a}-\mathrm{d}}$ Means with different superscripts within a column are significant at $p \leq 0.05$.

${ }^{1)}$ Viable cells were not detected at a detection limit at $10^{2} \mathrm{CFU} / \mathrm{g}$.

${ }^{2)}$ Standard errors of the mean $(\mathrm{n}=12)$.
kGy of gamma irradiation (Liu et al., 2009). Compared to the present result, gamma irradiation seems more effective than electron beam irradiation in eliminating microorganisms in shell egg. Generally, a somewhat weaker effect was observed in food irradiated with electron beams compared to gamma ray (Song et al., 2009a) due to the varying depths of penetration between the two radiation sources. Electron beams unlike gamma ray have limited penetration (Miller, 2005) and higher dosages (Ito et al., 1994), which may affect microbial inactivation on the size of packaging (Song et al., 2009a). Another concern is that the energy level of the electron beam irradiator used in this study $(2.5 \mathrm{MeV})$ could only provide limited penetration. Although shell eggs were placed evenly to improve the dose distribution, only one side was irradiated.

\section{Egg quality}

Table 2 shows the general quality of shell egg treated with electron beam irradiation. Irradiation did not have any effect on yolk color. In contrast, Huang et al. (1997) reported that egg yolk irradiated at $10 \mathrm{MeV}$ had a significantly higher yolk color than non-irradiated samples. The color change could have been caused by the destruction of carotenoids, which decompose in proportion to the amount of radiation (Katusin-Razem et al., 1992). However, this bleaching effect is insignificant compared to natural variations in pigment concentration that occur

Table 2. General quality of shell egg treated with electron beam irradiation during ambient storage

\begin{tabular}{ccccc}
\hline \hline $\begin{array}{c}\text { Storage } \\
\text { period (d) }\end{array}$ & $\begin{array}{c}\text { Irradiation } \\
\text { dose }(\mathrm{kGy})\end{array}$ & $\begin{array}{c}\text { Albumen } \\
\text { height }(\mathrm{mm})\end{array}$ & $\begin{array}{c}\text { Haugh } \\
\text { units }\end{array}$ & $\begin{array}{c}\text { Yolk color } \\
(\%)\end{array}$ \\
\hline 0 & 1 & $4.49^{\mathrm{a}}$ & $60.78^{\mathrm{a}}$ & 7.44 \\
0 & 2 & $0^{\mathrm{b}}$ & $0^{\mathrm{b}}$ & 7.44 \\
& 3 & $0^{\mathrm{b}}$ & $0^{\mathrm{b}}$ & 7.10 \\
& $0^{\mathrm{b}}$ & $0^{\mathrm{b}}$ & 6.80 \\
& $\mathrm{SEM}^{1)}$ & 0.18 & 1.99 & 0.33 \\
\hline 7 & 0 & $3.67^{\mathrm{a}}$ & $50.33^{\mathrm{a}}$ & 7.44 \\
& 1 & $0^{\mathrm{b}}$ & $0^{\mathrm{b}}$ & 7.33 \\
& 2 & $0^{\mathrm{b}}$ & $0^{\mathrm{b}}$ & 7.50 \\
& 3 & $0^{\mathrm{b}}$ & $0^{\mathrm{b}}$ & 7.20 \\
& $\mathrm{SEM}^{1)}$ & 0.32 & 3.37 & 0.33 \\
\hline & 0 & $2.42^{\mathrm{a}}$ & $33.07^{\mathrm{a}}$ & 7.67 \\
& 1 & $0^{\mathrm{b}}$ & $0^{\mathrm{b}}$ & 7.56 \\
& 2 & $0^{\mathrm{b}}$ & $0^{\mathrm{b}}$ & 7.40 \\
& 3 & $0^{\mathrm{b}}$ & $0^{\mathrm{b}}$ & 7.30 \\
& $\mathrm{SEM}^{1)}$ & 0.09 & 1.68 & 0.26 \\
\hline
\end{tabular}

${ }^{\mathrm{a}-\mathrm{b}}$ Means with different superscripts within a column are significant at $p \leq 0.05$.

${ }^{1)}$ Standard errors of the mean $(n=12)$. 
among different samples (Brooks et al., 1959).

Albumen height and Haugh units were both reduced upon electron beam irradiation, thus indicating a loss of freshness. Ma (1996) reported that irradiation results in a decrease in the number of Haugh units at 1-3 kGy. The main explanation for this phenomenon is that the irradiation treatment ruptured the albuminous sac, resulting in the loss of thick albumen most likely due to the irradiation-induced scission of $O$-glycosides from ovomucin protein (Ma, 1996). This is one of the major changes in quality for irradiated shell egg (Liu et al., 2009).

\section{Functional properties}

The emulsion capacity of shell eggs did not change upon electron beam irradiation (Table 3). Huang et al. (1997) reported that egg yolk electron beam irradiated at $10 \mathrm{MeV}$ had significantly higher emulsion capacity than non-irradiated samples, and the differences were significant within the first $7 \mathrm{~d}$ of frozen storage. Previous studies demonstrated that differences in emulsion capacity were observed for eggs treated with gamma irradiation (Liu et al., 2009; Ma et al., 1990). The major differences in the results must be due to the penetration power and dose rate.

The viscosity of irradiated egg white decreased significantly with increased irradiation dose (Table 3 ). Chain scission reduces the number of peptide linkages in irradiated eggs, thereby decreasing the viscosity. This result is in accordance with previous studies using gamma ray
(Ma et al., 1990; Pinto et al., 2004). The irradiation of proteins is known to cause denaturation as well as the formation of protein radicals due to interactions with water, resulting in reactions with constituent amino acid subunits (Stewart, 2001). Yang and Balwin (1995) suggested that changes in the viscosity of egg white were associated with the unfolding and aggregation of egg white proteins. They also showed that the viscosity of egg white is positively related to foaming ability, as most protein systems with high viscosity exhibit surface tension dependence (Phillips et al., 1994). Song et al. (2009b) found that irradiated liquid egg white with reduced viscosity may also have decreased surface tension, which creates a large surface area that is essential for foaming.

Protein foams are characterized by two factors, namely foaming ability and foam stability (Song et al., 2009b). Foaming ability was increased significantly while foam stability was decreased upon irradiation during storage at room temperature (Table 3). Ma et al. (1990) reported that foaming ability is improved by irradiation due to conformational changes of proteins in the egg white that increase surface hydrophobicity and lower viscosity. Clark et al. (1992) also reported improved functional properties for spray-dried egg white irradiated at $2 \mathrm{kGy}$ or above. This is because irradiation causes small changes in secondary structures (i.e., from $\alpha$-helix to random structure), thus enhancing some functional properties. Further, heattreatment at high temperature (above $55^{\circ} \mathrm{C}$ ) seems to enhance these protein-protein interactions at the interface,

Table 3. Functional properties of shell egg treated with electron beam irradiation during ambient storage

\begin{tabular}{|c|c|c|c|c|c|c|c|}
\hline $\begin{array}{l}\text { Storage period } \\
\text { (d) }\end{array}$ & $\begin{array}{l}\text { Irradiation dose } \\
(\mathrm{kGy})\end{array}$ & $\begin{array}{c}\text { Emulsion } \\
\text { capacity (\%) }\end{array}$ & $\begin{array}{c}\text { Viscosity } \\
\text { (white, } \mathrm{mPa} \cdot \mathrm{s} \text { ) }\end{array}$ & $\begin{array}{l}\text { Foaming ability } \\
(\mathrm{mm})\end{array}$ & $\begin{array}{l}\text { Foam stability } \\
(\mathrm{mm})\end{array}$ & $\mathrm{pH}$ (white) & $\mathrm{pH}$ (yolk) \\
\hline \multirow{5}{*}{0} & 0 & 41.46 & $19.50^{\mathrm{a}}$ & $27.50^{\mathrm{b}}$ & $12.00^{\mathrm{b}}$ & 9.78 & 6.38 \\
\hline & 1 & 42.92 & $10.50^{\mathrm{b}}$ & $48.50^{\mathrm{a}}$ & $22.50^{\mathrm{a}}$ & 9.80 & 6.29 \\
\hline & 2 & 40.92 & $9.50^{\mathrm{b}}$ & $54.50^{\mathrm{a}}$ & $26.50^{\mathrm{a}}$ & 9.78 & 6.38 \\
\hline & 3 & 43.26 & $9.00^{\mathrm{b}}$ & $46.50^{\mathrm{a}}$ & $24.50^{\mathrm{a}}$ & 9.77 & 6.35 \\
\hline & SEM $^{1)}$ & 0.62 & 0.61 & 3.24 & 2.52 & 0.09 & 0.04 \\
\hline \multirow{5}{*}{7} & 0 & 45.10 & $18.50^{\mathrm{a}}$ & $29.00^{b}$ & $17.50^{\mathrm{b}}$ & 10.08 & 6.43 \\
\hline & 1 & 45.94 & $6.50^{\mathrm{b}}$ & $50.50^{\mathrm{ab}}$ & $27.50^{\mathrm{ab}}$ & 10.05 & 6.39 \\
\hline & 2 & 43.38 & $6.00^{\mathrm{b}}$ & $60.50^{\mathrm{a}}$ & $33.50^{\mathrm{a}}$ & 10.08 & 6.37 \\
\hline & 3 & 43.07 & $6.00^{\mathrm{b}}$ & $42.50^{\mathrm{ab}}$ & $29.00^{\mathrm{ab}}$ & 10.05 & 6.37 \\
\hline & SEM $^{1)}$ & 3.30 & 0.50 & 5.37 & 3.52 & 0.02 & 0.03 \\
\hline \multirow{5}{*}{14} & 0 & 44.51 & $20.0^{a}$ & $37.50^{b}$ & $17.50^{\mathrm{c}}$ & 10.46 & 6.52 \\
\hline & 1 & 44.98 & $7.00^{\mathrm{b}}$ & $61.00^{\mathrm{a}}$ & $25.00^{\mathrm{b}}$ & 10.47 & 6.46 \\
\hline & 2 & 44.15 & $6.50^{\mathrm{b}}$ & $67.50^{\mathrm{a}}$ & $34.50^{\mathrm{a}}$ & 10.45 & 6.52 \\
\hline & 3 & 43.47 & $6.00^{\mathrm{b}}$ & $57.50^{\mathrm{a}}$ & $32.50^{\mathrm{a}}$ & 10.46 & 6.66 \\
\hline & SEM $^{1)}$ & 2.75 & 1.46 & 3.14 & 1.84 & 0.02 & 0.03 \\
\hline
\end{tabular}

\footnotetext{
${ }^{a-c}$ Means with different superscripts within a column are significant at $p \leq 0.05$
}

${ }^{1)}$ Standard errors of the mean $(\mathrm{n}=12)$. 
possibly due to interactions between heat-exposed hydrophobic groups or sulfhydryl groups (Van der Planket et al., 2006). Foam stability is important for the shelf life and product appearance of food foams and must be maintained during exposure to a variety of processes such as heating, mixing, and cutting (Foegeding et al., 2006). Song et al. (2009b) obtained a similar result using gamma irradiated eggs, reporting that irradiation of egg white offers advantages for increasing foaming ability, improving the quality of final bakery products, and reducing the microbial load in egg white.

The $\mathrm{pH}$ values of egg yolk and egg white did not change upon electron beam irradiation (Table 3 ). In contrast, the $\mathrm{pH}$ levels of gamma irradiated egg white and egg yolk were increased by increased irradiation (Liu et al., 2009). Further, Huang et al. (1997) reported that the $\mathrm{pH}$ of electron beam irradiated $(10 \mathrm{MeV})$ egg yolk was significantly higher than that of the non-processed sample.

\section{2-Thiobarbituric acid reactive substance (TBARS) values}

One of the concerns regarding irradiated foods rich in fat content is the acceleration of lipid oxidation. The TBARS values of egg yolk were increased by irradiation and also during storage (Table 4). Fresh shell egg lipids are not easily oxidized (Pike and Peng, 1985) since the structure of phospholipids in the yolk aids in the prevention of oxidation (Burley and Vadehar, 1989). However, Liu et al. (2009) reported that gamma irradiation increases the oxidation of polyunsaturated fatty acids in shell egg while chitosan coating may retard the development of lipid oxidation.

In conclusion, electron beam irradiation can, similar to the effects of gamma ray, reduce the freshness of shell egg while increasing the oxidation of egg white. However, this method may improve important functional

Table 4. 2-Thiobarbituric acid reactive substances values (mg malondialdehyde $/ \mathrm{kg}$ ) of egg yolk treated with electron beam irradiation during ambient storage

\begin{tabular}{cccc}
\hline \hline \multirow{2}{*}{$\begin{array}{c}\text { Irradiation dose } \\
(\mathrm{kGy})\end{array}$} & 0 & 7 & Storage period (d) \\
\cline { 2 - 4 } & $0.87^{\mathrm{b}}$ & $0.86^{\mathrm{d}}$ & 0.86 \\
0 & $1.02^{\mathrm{a}}$ & $0.99^{\mathrm{c}}$ & 1.00 \\
1 & $1.10^{\mathrm{a}}$ & $1.08^{\mathrm{b}}$ & 1.09 \\
2 & $1.12^{\mathrm{a}}$ & $1.14^{\mathrm{a}}$ & 1.20 \\
3 & 0.03 & 0.01 & 0.01 \\
SEM $^{1)}$ & &
\end{tabular}

$\overline{\mathrm{a}-\mathrm{d}}$ Means with different superscripts within a column are significant at $p \leq 0.05$.

${ }^{1)}$ Standard errors of the mean $(n=12)$. properties such as foaming capacity. It also can be applied to the egg breaking process because the reduced viscosity of egg white can increase the separation efficiency of egg white and yolk.

\section{Acknowledgement}

This work was financially supported by the Rural Development Administration, Korea.

\section{References}

1. Brooks, J., Hannan, R. S., and Hobbs, B. C. (1959) Irradiation of eggs and egg products. Int. J. Appl. Radiat. Isot. 6, 149-154.

2. Burley, R. W. and Vadehra, D. V. (1989) Egg yolk: Structure and properties. In The Avian Egg. Burley, R. W. and Vadehra, D. V. (ed.) pp. 171-233. John Wiley \& Sons, New York, NY.

3. Centers for Disease Control (2003) Outbreaks of Salmonella serotype enteritidis infection associated with eating shell eggs- United States, 1999-2001. Morb. Mortal. Wkly. Rep. 51, 1149-1152.

4. Cho, J. M., Park, S. K., Lee, Y. S., and Rhee, C. O. (2002) Effects of soy protein isolate coating on egg breakage and quality of eggs during storage. Food Sci. Biotechnol. 11, 392-396.

5. Clark, D. C., Kiss, I. F., Wilde, P. J., and Wilson, D. R. (1992) The effect of irradiation on the functional properties of spray-dried egg white protein. Food Hydrocolloid 5, 541548.

6. Foegeding, E. A., Luck, P. J., and Davis, J. P. (2006) Factors determining the physical properties of protein foams. Food Hydrocolloid 20, 284-292.

7. Frazier, W. C. and Westhoff, D. C. (1988) Contamination, preservation, and spoilage of eggs. In W. C. Frazier, and Westhoff, D. C. (ed), Food microbiology (4th ed.) pp. 255267. New York: McGraw-Hill.

8. Huang, S., Herald, T. J., and Mueller, D. D. (1997) Effect of electron beam irradiation on physical, physicochemical, and functional properties of liquid egg yolk during frozen storage. Poultry Sci. 76, 1607-1615.

9. Ito, H. and Islam, M. S. (1994) Effect of dose rate on inactivation of microorganisms in spices by electron beams and gamma-rays irradiation. Radiat. Phys. Chem. 43, 545-550.

10. Jo, C., Ahn, D. U., and Byun, M. W. (2002) Irradiation induced oxidative changes and production of volatile compounds in sausage prepared with vitamin E-enhanced commercial soybean oil. Food Chem. 76, 299-305.

11. Katusin-Razen, B., Mihaljevic, B., and Razem, D. (1992) Radiation-induced oxidative chemical changes in dehydrated egg products. J. Agric. Food Chem. 40, 662-668.

12. Kim, D. H., Yun, H. J., Song, H. P., Lim, B. L., and Jo, C. (2008) Isolation of egg-contaminating bacteria and evalua- 
tion of bacterial radiation sensitivity. Korean J. Food Preserv. 15, 774-781.

13. Liu, X. D., Jang, A., Kim, D. H., Lee, B. D., Lee, M., and Jo, C. (2009) Effect of combination of chitosan coating and irradiation on physicochemical and functional properties of chicken egg during room-temperature storage. Radiat. Phys. Chem. 78, 589-591.

14. Ma, C. Y. (1996) Effect of gamma irradiation on physicochemical and functional properties of egg and egg products. Radiat. Phys. Chem. 48, 375.

15. Ma, C. Y., Sahasrabudhe, M. R., Poste, L. M., Harwalkar, V. R., and Chambers, J. R. (1990) Gamma irradiation of shell eggs. Internal and sensory quality, physicochemical characteristics, and functional properties. Canadian Ins. Food Sci. Technol. J. 23, 226-232.

16. Miller, R. B. (2005) Food irradiation using electron beams. In Miller, R. B. (ed). Electronic irradiation of foods. Springer, New York. pp. 43-74.

17. Mitchell, G. E. (1994) Irradiation preservation of meats. Food Australia, 46, 512-516.

18. Narvaiz, P., Lescano, G., and Kairiyama, E. (1992) Physicochemical and sensory analyses on egg powder irradiated to inactivate Salmonella and reduce microbial load. J. Food Safety 12, 263-282.

19. Patrick, M. E., Adcock, P. M., Gomez, T. M., Altekruse, S. F., Holland, B. H., Tauxe, R. V., and Swerdlow, D. L. (2004) Salmonella Enteritidis infections, United States, 1985-1999. Emerg. Infect. Dis. 10, 1-7.

20. Phillips, L. G., German, J. B., Focgeding, E. A., Harwalkar, A., Kilara, B. A., Lewins, B. A., Mangino, M. E., Morr, C. V., Regenstein, J. M., Smith, D. M., and Kinsella, J. E. (1990) Standardized procedure for measuring foaming properties of three proteins, a collaborative study. J. Food Sci. 55, 1441-1444.

21. Phillips, L. G., Whitehead, D. M., and Kinsella, J. (1994) Structure-Function properties of food proteins. Academic Press, San Diego.

22. Pike, O. A. and Peng, I. C. (1985) Stability of shell egg and liquid yolk to lipid oxidation. Poultry Sci. 64, 1470-1475.

23. Pinto, P., Ribeiro, R., Sousa, L., Cabo Verde, S., Lima, M. G., Dinis, M., Santana, A., and Botelho, M. L. (2004) Sanitation of chicken eggs by ionizing radiation: functional and nutri- tional assessment. Radiat. Phys. Chem. 71, 33-36.

24. Serrano, L. E., Murano, E. A., Shenoy, K., and Olson, D. G. (1997) D Values of Salmonella enteritidis isolates and quality attributes of shell eggs and liquid whole eggs treated with irradiation. Poultry Sci. 76, 202-205.

25. Sommers, C. H. and Fan, X. (2006) Food irradiation research and technology. $1^{\text {st }}$ ed. IFT Press Series.

26. Song, H. P., Kim, B., Choe, J. H., Jung, S., Kim, K. S., Kim, D. H., and Jo, C. (2009a) Improvement of foaming ability of egg white product by irradiation and its application. Radiat. Phys. Chem. 78, 217-221.

27. Song, H. P., Kim, B., Jung, S., Choe, J. H., Yun, H., Kim, Y. J., and Jo, C. (2009b) Effect of gamma and electron beam irradiation on the survival of pathogens inoculated into salted, seasoned, and fermented oyster. LWT-Food Sci. Technol. 42, 1320-1324.

28. Stewart, E. M. (2001) Food Irradiation Chemistry. In Molins, R. A. (ed), Food Irradiation: Principles and Applications. Wiley-Interscience, New York.

29. Theron, H. Venter, P., and Lues, J. F. R. (2003) Bacterial growth on chicken eggs in various storage environments. Food Res. Int. 36, 969-975.

30. Tellez, I. G., Trejo, R. M., Sanchez, R. E., Ceniceros, R. M., Luna, Q. P., Zazua, P., and Hargis, B. M. (1995) Effect of gamma irradiation on commercial eggs experimentally inoculated with Salmonella Enteritidis. Radiat. Phys. Chem. 46, 789-792.

31. USDA-Food Safety and Inspection Service (2000) Irradiation in the production, processing and handling of food-Shell eggs, fresh; safe use of ionizing radiation for salmonella reduction. Fed. Regist. 65, 45280-45282.

32. Van der Plancken, I., Van Loey, A., and Hendrickx, M. (2006) Effect of heat treatment on the physico-chemical properties of egg white proteins: A kinetic study. J. Food Eng. 75, 316-326.

33. Yang, S. C. and Baldwin, R. E. (1995) Functional properties of eggs in foods. In: Stadelman, W. J., Cotterill, O. J. (ed), Egg Science and Technology, 4th ed. Food Products Press, New York.

(Received 2010.5.31/Revised 1st 2010.6.10, 2nd 2010.7.9/ Accepted 2010.7.13) 